\title{
Characterization of Bergenin in Endopleura uchi Bark and its Anti-Inflammatory Activity
}

\author{
Rita C. S. Nunomura, ${ }^{*, a, b}$ Viviane G. Oliveira, ${ }^{a, b}$ Saulo L. Da Silva ${ }^{b}$ and Sergio M. Nunomura ${ }^{a}$ \\ ${ }^{a}$ Coordenação em Pesquisas de Produtos Naturais, Instituto Nacional de Pesquisas da Amazônia, \\ 69083-000 Manaus-AM, Brazil \\ ${ }^{b}$ Departamento de Química, Instituto de Ciências Exatas, Universidade Federal do Amazonas, \\ 69077-000 Manaus-AM, Brazil
}

\begin{abstract}
Endopleura uchi (Huber) Cuatrec. é uma planta medicinal da Amazônia utilizada no tratamento de inflamações e doenças do aparelho reprodutor feminino. A bergenina pura foi isolada do extrato metanólico das cascas de E. uchi, inicialmente por um processo de partição líquido-líquido, seguido de cromatografia em coluna de permeação em gel Sephadex LH-20 e finalmente de adsorção utilizando sílica gel 60. A elucidação estrutural foi determinada pela análise dos espectros de RMN. A atividade anti-inflamatória in vitro foi determinada pela medida da concentração inibitória (CI) da bergenina frente a três importantes enzimas: COX-1, COX-2 (ciclooxigenases) e fosfolipase $\mathrm{A}_{2}\left(\mathrm{PLA}_{2}\right)$. Essas enzimas foram selecionadas, porque são importantes alvos terapêuticos no processo de descobrimento de novas drogas anti-inflamatórias associadas com a biossíntese das prostaglandinas. $\mathrm{A} \mathrm{CI}_{50}$ da bergenina para a fosfolipase $\mathrm{A}_{2}$ foi de $156,6 \mu \mathrm{mol} \mathrm{L} \mathrm{L}^{-1}$. Comparada ao padrão de tioeteramida $\mathrm{PC}$, bergenina foi considerada pouco ativa. A bergenina também não foi capaz de inibir COX-1 $\left(\mathrm{CI}_{50}=107,2 \mu \mathrm{mol} \mathrm{\textrm {L } ^ { - 1 }}\right)$. Entretanto, bergenina foi capaz de inibir seletivamente COX-2 $\left(\mathrm{CI}_{50}=1,2 \mu \mathrm{mol} \mathrm{L}{ }^{-1}\right)$. Considerando o uso de E. uchi na medicina tradicional, a quantidade de bergenina no extrato aquoso preparado da forma popular foi quantificado por CLAE em fase reversa como sendo 3\% nas cascas. Esses resultados indicam uma alta concentração de bergenina nos chás e nas cascas. A atividade inibitória seletiva para COX-2 também é importante, uma vez que inibidores seletivos de COX-2 têm sido clinicamente validados como drogas antiinflamatórias por sua eficácia e por não apresentar efeitos gastrintestinais colaterais.
\end{abstract}

Endopleura uchi (Huber) Cuatrec. is an Amazon species traditionally used for the treatment of inflammations and female disorders. Pure bergenin was isolated from the methanolic extract of bark of E. uchi, firstly by using liquid-liquid partition chromatography followed by column chromatography over Sephadex LH-20 and then silica gel 60 flash chromatography. The structure of bergenin was identified on the basis of its NMR spectra. The in vitro anti-inflammatory activity was determined by the measurement of the inhibitory concentration (IC) of bergenin against three key enzymes: COX-1, COX-2 (cyclooxygenases) and phospholipase $\mathrm{A}_{2}\left(\mathrm{PLA}_{2}\right)$. These enzymes were selected because they are important targets for the discovery of new anti-inflammatory drugs associated with the biosynthesis of prostaglandins. The $\mathrm{IC}_{50}$ of bergenin for phopholipase $\mathrm{A}_{2}$ was determined as $156.6 \mu \mathrm{mol} \mathrm{\textrm {L } ^ { - 1 }}$ and bergenin was not considered active as compared to the positive control, tioetheramide PC. Bergenin did not inhibit COX-1 as well $\left(\mathrm{IC}_{50}=107.2 \mu \mathrm{mol} \mathrm{L} \mathrm{L}^{-1}\right)$. However, bergenin selectively inhibited COX-2 $\left(\mathrm{IC}_{50}=1.2 \mu \mathrm{mol} \mathrm{L} \mathrm{L}^{-1}\right)$. Because of the use of $E$. $u c h i$ in traditional medicine, bergenin was quantified in teas prepared as prescribed in traditional medicine by RP-HPLC as being $3 \%$ in the bark of $E$. uchi. The inhibitory activity towards COX-2 is important, since selective inhibitors of COX-2 have been clinically validated as anti-inflammatory therapeutics due to their enhanced gastrointestinal safety.

Keywords: COX-1, COX-2, PLA 2 , quantification, Humiriaceae, Endopleura uchi

\section{Introduction}

The Brazilian Amazon encompasses some of the largest and least disturbed tracts of forest in the world. The

*e-mail: ritasn@ufam.edu.br sustainable study and use of Amazonian biodiversity is a unique challenge and opportunity for Brazil, and will most certainly generate new scientific knowledge. Particularly for a natural product chemist, Amazonian biodiversity holds an unbounded potential of chemical information. Gottlieb and his coworkers have called our attention to 
the potentialities of Amazonian flora, which contain many compounds of biological interest. ${ }^{1,2}$ The importance of the study of medicinal plants has been emphasized by the seminal work of Schultes in the Amazon. ${ }^{3}$

Endopleura uchi (Huber) Cuatrec. (Humiriaceae) is a species widespread in the Amazon basin, popularly known as "uxi-amarelo" or "uxi-liso". There have been few chemical studies of E. uchi uchi, and these have concentrated on the fruits, which are very much appreciated by the local population. The pulp of the fruit has a high content of fat, predominantly oleic acid ${ }^{4}$ and carotenoids, mostly trans- $\beta$-carotene. ${ }^{5}$ Bark tea of $E$. uchi is used in the traditional medicine as an anti-inflammatory and against tumors and uterine infections, ${ }^{6,7}$ and we have focused on the chemistry of this bark. We isolated bergenin, a $C$-glycoside of 4-O-methyl gallic acid, from E. uchi bark. Previously bergenin has been isolated from $E$. uchi fruits, ${ }^{5}$ and another Humiriaceae species, Humiria balsamifera Aubl. ${ }^{8}$ and Sacoglottis gabonensis. ${ }^{9}$ Bergenin has been reported to have several biological activities, such as anti-inflammatory, ${ }^{10,11}$ antioxidant, ${ }^{12}$ hepatoprotective, ${ }^{13}$ neuroprotective, ${ }^{14}$ anti$\mathrm{HIV}^{15}$ and antifungal. ${ }^{16,17}$ Here we report antiinflammatory activity of bergenin and the quantification of bergenin in an aqueous extract of bark, prepared as prescribed in the traditional medicine, by RP-HPLC. The inhibitory activity of bergenin against important enzymes (phospholipase $\mathrm{A}_{2}$ and cyclooxygenases) involved in inflammatory mechanisms was also evaluated. These enzymes are responsible for the synthesis of prostaglandins (PGs). Phospholipase $\left(\mathrm{PLA}_{2}\right)$ is an important tool in the search for potential inhibitors. This enzyme catalyses the hydrolysis of phospholipids to yield free fatty acids, such as arachidonic acid. ${ }^{18}$ Cyclooxygenases (COXs) catalyse the conversion of arachidonic acid into different PGs. There are two isoforms of COX, one is constitutive $(\mathrm{COX}-1)$ and the other is inducible (COX-2). COX-1 is responsible for physiological levels of prostaglandins. COX-2 is induced by pro-inflammatory stimuli. COX-2 is expressed by inflammatory cells and is responsible for the high levels of PGs present in acute and chronic inflammations. ${ }^{19,20}$

\section{Experimental}

\section{Plant material}

The barks of E. uchi were collected in the Adolpho Ducke Reserve (INPA) located $23 \mathrm{~km}$ from Manaus (AM), Brazil, and identified by the botanist G. T. Prance. Voucher specimens were deposited in the INPA herbarium with numbers 177673 and 177660 .

\section{Extraction and isolation of bergenin}

All solvents used for extraction and isolation were analytical grade. Air-dried powdered trunk bark $(2.9 \mathrm{~kg})$ was extracted by maceration in hexanes for 3 weeks and the solvent replaced 3 times. The extracts were concentrated until dryness and $4.8 \mathrm{~g}$ of hexane extract was obtained. After the extraction with hexanes, the barks were extracted with methanol for 3 weeks and the solvent replaced 3 times. These extracts were concentrated under vacuum and yielded $266.8 \mathrm{~g}$ of extract. Part of the methanol extract (110.0 g) was redissolved in $\mathrm{MeOH} / \mathrm{H}_{2} \mathrm{O}$ (9:1) and partitioned into hexanes, chloroform, and ethyl acetate. The four resulting fractions were concentrated under mild conditions until dryness and yielded 1.1, 6.5, 39.6, and $62.0 \mathrm{~g}$ of hexanes, chloroform, ethyl acetate, and hydroalcoholic fractions, respectively. Then, $1.0 \mathrm{~g}$ of the ethyl acetate fraction was purified over Sephadex LH-20, being eluted with methanol to afford 22 fractions. The first fraction was further purified by silica flash column, being eluted in a stepwise gradient first with $100 \%$ ethyl acetate, then with ethyl acetate/ methanol (9:1) and finally $100 \% \mathrm{MeOH}$. The fractions 3 to 7, eluted with EtOAc/MeOH (9:1), were dried and recrystalized with ethyl acetate, yielding $37.0 \mathrm{mg}$ of a colorless crystal identified as bergenin.

\section{Identification and characterization of bergenin}

Bergenin was identified on the basis of its NMR spectrum, which was compared with data reported in the literature. ${ }^{21,22}$ The bergenin structure is shown in Figure 1. NMR spectra were recorded on a Varian Inova-500 spectrometer. Standard pulse sequences were employed for the measurement of $2 \mathrm{D}$ NMR spectra (1H-1H COSY, HSQC, HMBC, and NOESY). NMR data were collected at room temperature. ${ }^{1} \mathrm{H}$ NMR (500 MHz, CD 3 OD-d4): $\delta 7.09$ (s, 1H, H-4); 4.94 (d, 10, 1H, H-9); 3.68 (m, 1H, H-11); 3.43 (dd, 9.5; 8.5, 1H, H-12); 3.81 (dd, 9.5; 8.5, 1H, H-13); 4.07 (dd, 9.5; 10.0, 1H, H-14); 3.91 (s, 3H, OMe); 3.68 (m, 1H, H-16); 4.03 (dd, 10.7; 2.5, 1H, H-16). ${ }^{13} \mathrm{C} \mathrm{NMR}\left(125 \mathrm{MHz}, \mathrm{CD}_{3} \mathrm{OD}-\mathrm{d} 4\right): \delta 164.6(\mathrm{C}-2)$; 151.1 (C-5); 141.1 (C-6); 148.2(C-7); 116.1 (C-8); 118.2 (C3); 109.9 (C-4); 73.1 (C-9); 81.9 (C-11); 70.7 (C-12); 74.4 (C-13); 80.2 (C-14); 59.8 (C-15); 61.5 (C-16).

\section{Cyclooxygenase assay}

The effect of bergenin on COX-1 and COX-2 was determined by measuring prostaglandin E2 (PGE2) levels using a COX Inhibitor Screening Kit from Cayman Chemicals, Michigan, USA. ${ }^{23}$ Reaction mixtures were prepared in $100 \mathrm{mmol} \mathrm{L}^{-1}$ Tris- $\mathrm{HCl}$ buffer, $\mathrm{pH} 8.0$, containing $1 \mu \mathrm{mol} \mathrm{L} \mathrm{L}^{-1}$ heme and COX-1 (ovine) or COX-2 (human recombinant) and preincubated for $10 \mathrm{~min}$ in a 


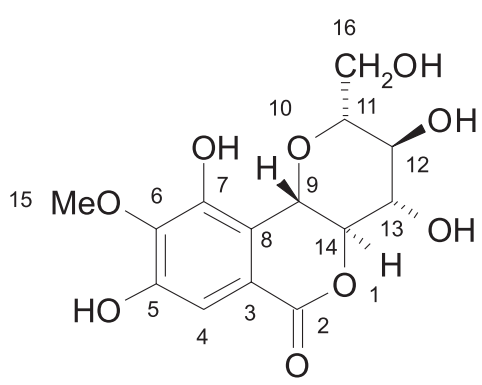

Figure 1. Bergenin structure.

waterbath $\left(37^{\circ} \mathrm{C}\right)$. The reaction was initiated by the addition of $10 \mu \mathrm{L}$ arachidonic acid to yield a final concentration in the reaction mixture of $100 \mu \mathrm{mol} \mathrm{L}^{-1}$. After $2 \mathrm{~min}$, the reaction was terminated by adding $1 \mathrm{~mol} \mathrm{~L}^{-1} \mathrm{HCl}$. Then $\mathrm{PGE}_{2}$ was quantified by an ELISA method. The test compounds were dissolved in DMSO and diluted to the desired concentration with $100 \mathrm{mmol} \mathrm{L}^{-1}$ potassium phosphate buffer ( $\mathrm{pH}$ 7.4). Following transfer to a 96-well plate coated with a mouse anti-rabbit IgG, the tracer prostaglandin, acetylcholine esterase and primary antibody (mouse anti PGE2) were added. Plates were then incubated at room temperature overnight, reaction mixtures were removed, and wells were washed with $10 \mathrm{mmol} \mathrm{L}^{-1}$ potassium phosphate buffer containing $0.05 \%$ Tween 20 . Ellman's reagent $(200 \mu \mathrm{L})$ was added to each well and the plate was incubated at room temperature in the dark for $60 \mathrm{~min}$, until the control wells yielded an OD between 0.3-0.8 at $412 \mathrm{~nm}$. A standard curve with $\mathrm{PGE}_{2}$ was generated from the same plate, which was used to quantify the PGE2 levels produced in the presence of bergenin. Results were expressed as a percentage relative to a control (solvent-treated samples, instead of samples). All determinations were performed in triplicate with six repetitions. Dose-response curves were generated for the calculation of $\mathrm{IC}_{50}$ values. The measured values, significances, were evaluated by using the Student $t$-test. Values with $\mathrm{P}<0.05$ were considered significant.

\section{Phospholipase $A_{2}$ assay}

The phospholipase activity was measured by using HPGP (1-hexadecanoyl-2-(10-pyrenyldecanoyl)$s n$-glycero-3-phosphoglycerol) as substrate through microtitration on 96-well plate. In each well of a 96-well microtiter plate, $100 \mu \mathrm{L}$ of buffer solution A containing $27 \mu \mathrm{mol} \mathrm{L} \mathrm{L}^{-1}$ bovine serum albumin, $50 \mathrm{mmol} \mathrm{L}^{-1} \mathrm{KCl}$, $1 \mathrm{mmol} \mathrm{L}^{-1} \mathrm{CaCl}_{2}$, and $50 \mathrm{mmol} \mathrm{L}^{-1}$ Tris- $\mathrm{HCl}, \mathrm{pH}$ 8.0, was added, followed by the addition of a bergenin solution in DMSO $\left(0.01-1000 \mu \mathrm{mol} \mathrm{L}^{-1}\right)$ or solely DMSO in the control. Buffer solution B was prepared from buffer solution A by adding $0.5 \mu \mathrm{gL}^{-1} \mathrm{PLA}_{2}$ (Bothrops jararacussu). $100 \mu \mathrm{L}$ of buffer $\mathrm{B}$ was transferred into each well, then $100 \mu \mathrm{L}$ of solution $\mathrm{C}$, buffer solution A containing $4.2 \mathrm{mmol} \mathrm{L}^{-1} \mathrm{HGPH}$. The fluorescence (excitation at $342 \mathrm{~nm}$, emission at $395 \mathrm{~nm}$ ) was measured with a spectrophotometer (Fluorocount, Packard Inst.). Pure DMSO was used as control of phospholipase activity and thioetheramide PC as phospholipase inhibitor. ${ }^{24}$ Six repetitions of three independent experiments were performed to ensure the results. The statistical significance was determined by one-way analysis of variance with the Student $t$-test. The minimum level of significance considered was $\mathrm{P}<0.5$.

\section{Preparation of aqueous extract solution}

The aqueous extract was prepared as prescribed in traditional medicine, a decoction for $5 \mathrm{~min}$ of $c a .30 \mathrm{~g}$ of bark in a half liter of deionized water. This extract was concentrated under vacuum until dryness.

\section{Preparation of the calibration curve for HPLC analysis}

Pure bergenin isolated from the bark of E. uchi was used as standard. Different concentrations of bergenin were prepared in methanol from a solution of $1.0 \mathrm{mg} \mathrm{mL}^{-1}$ by successive dilutions at final concentrations of 6.25 to $100 \mu \mathrm{g} \mathrm{mL}{ }^{-1}$. Calibration curves of bergenin were constructed by triplicate intra-day and inter-day analyses to ensure the robustness of the method.

\section{HPLC analysis}

The HPLC system consisted of a quaternary pump LC-10AT, a SPDM-20A photodiode-array detector (DAD), a SIL-20A automatic injector and a workstation running LC Solutions software, all from Shimadzu, Inc. TFA (trifluoroacetic acid) was of analytical grade from SigmaAldrich. The water for HPLC analysis was purified through a Millipore Simplicity 185 System. Methanol was of HPLC grade. The quantification of bergenin used the external standardization method by RP-HPLC with the following conditions: a LiChrospher $100 \mathrm{RP}-18 \mathrm{e}(250 \times 4.0 \mathrm{~mm}, 5 \mu \mathrm{m}$ particle size and 120 A pore size) column from Merck AG, eluted in the isocratic mode using as mobile phase $15 \%$ $\mathrm{MeOH}$ in aqueous TFA (pH 2.0) at flow rate of $1.0 \mathrm{~mL} \mathrm{~min}^{-1}$, $50 \mu \mathrm{L}$ injection (duplicate) and chromatograms quantified at 215,254 and $272 \mathrm{~nm}$.

\section{Results and Discussion}

Bergenin could be isolated in pure form from the bark extract of E. uchi. The structure elucidation of bergenin 
was established by NMR analysis (1D and 2D). The UV spectrum of bergenin in methanol showed two maxima at 215 and $272 \mathrm{~nm}$.

\section{Anti-inflammatory activity}

E. uchi barks are used traditionally in the Amazon as anti-inflammatory. The compound isolated from E. uchi, identified as bergenin, ${ }^{22}$ was evaluated for inhibitory activity against three important enzymes that catalyze reactions to yield prostaglandins, and are involved in inflammatory process: phospholipase $\mathrm{A}_{2}, \mathrm{COX}-1$ and $\mathrm{COX} 2$ and the results are shown in Table 1.

Table 1. Inhibitory activity of bergenin against phospholipase $\left(\mathrm{PLA}_{2}\right)$ and cyclooxygenases (COX-1/COX-2)

\begin{tabular}{lccc}
\hline & \multicolumn{3}{c}{$\mathrm{IC}_{50} /\left(\mu \mathrm{mol} \mathrm{L}^{-1}\right)$} \\
\cline { 2 - 4 } & $\mathrm{PLA}_{2}$ & $\mathrm{COX}-1$ & $\mathrm{COX}-2$ \\
\hline Bergenin & 156.6 & 107.2 & 1.2 \\
Thioeteramide-PC & 2.1 & - & - \\
resveratrol & - & 3.1 & - \\
Niflumic acid & - & - & 0.2 \\
\hline
\end{tabular}

Compared to thioetheramide-PC, a known inhibitor of PLA2, bergenin was $c a$. 70-fold less active. In the COX-1 assay, bergenin was also not as active as the positive control, resveratrol, being 50 fold less active. However, bergenin showed good inhibitory activity towards COX-2 compared to the positive control, niflumic acid. Based on the $\mathrm{IC}_{50}$ ratio values for COX-1/COX-2, bergenin showed a good selective inhibition of COX-2 with a selectivity index of 89.3. COX-2 is the principal isoform of COX that participates in inflammation, and the induction of COX-2 is responsible for the production of PGs at the site of inflammation. In addition, COX-2 has an important role in carcinogenesis, considering that COX-2 is over-expressed in human colon adenomas and carcinomas. ${ }^{25}$ On the other hand, some studies showed that COX-1 inhibitors often cause gastrointestinal side effects. ${ }^{23}$

\section{Analysis of bergenin by HPLC}

Since bergenin presents selective inhibitory activity against COX-2 and bergenin is the main component of the tea bark, which is used for the treatment of uterine inflammations and miomas in traditional medicine, the concentration of bergenin in the tea bark was determined by HPLC. The yield of aqueous extract prepared by decoction was $13.3 \%$. The RP-HPLC analysis was performed in the isocratic mode using the conditions previously described.
A standard of bergenin was prepared at a concentration of $1.0 \mathrm{mg} \mathrm{mL}^{-1}$ and eluted at 16 minutes. It was considered pure (Figure 2A). The aqueous extract of bark from E. uchi was also analysed at the initial concentration of $1.0 \mathrm{mg} \mathrm{mL}^{-1}$ (Figure 2B) and bergenin could also be easily identified by the co-elution method and was well-separated.

The calibration standards of bergenin were prepared in triplicate and plotting peak area against the concentration of bergenin resulted in the calibration curve. The robustness of the method was determined by the determination of accuracy and the inter-day and intra-day variability of the method. Three samples of tea bark were prepared and analyzed in three non-consecutive days. The selectivity of bergenin in each chromatogram was ensured by the peak purity check of bergenin peak for each analytical run. The calibration curves were built with five different concentrations of bergenin (concentration range from 6.25 to $100.00 \mu \mathrm{gL}^{-1}$ ) to with excellent linearity. At $272 \mathrm{~nm}$, the regression equation found was $\mathrm{y}=74.012 . \mathrm{x}-99.821$, with a correlation coefficient of 0.9999 . At $254 \mathrm{~nm}$, the regression
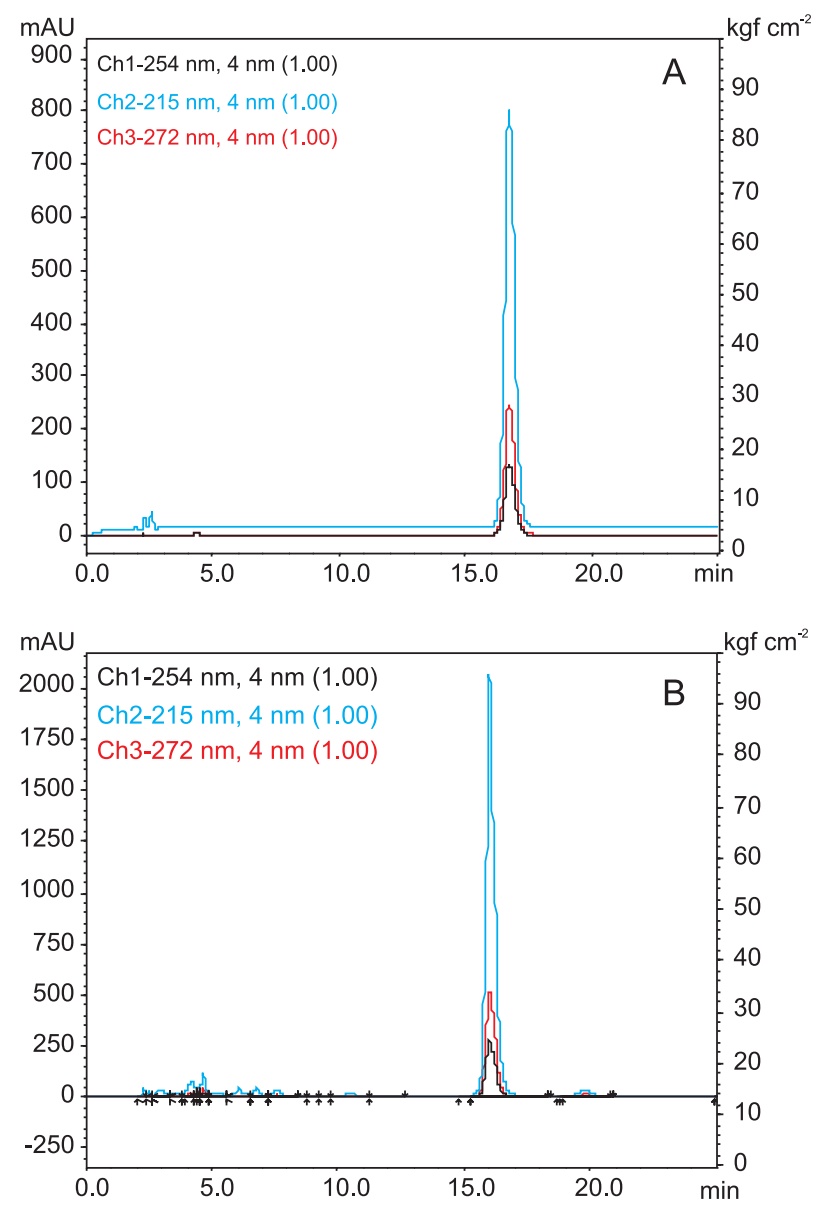

Figure 2. (A) Chromatograms of pure bergenin detected at 215, 254 and $272 \mathrm{~nm}$; (B) Chromatograms of aqueous bark extract from E. uchi showing bergenin as the majority compound at 215, 254 and $272 \mathrm{~nm}$ $(\mathrm{RT}=16.0 \mathrm{~min})$ 
Table 2. Results of the quantification of bergenin in E. uchi

\begin{tabular}{lcccc}
\hline$\lambda / \mathrm{nm}$ & $\begin{array}{c}\text { Bergenin in tea / } \\
\left(\mu \mathrm{g} \mathrm{mL}^{-1}\right)\end{array}$ & $\mathrm{CV} /(\%)$ & $\begin{array}{c}\text { Bergenin in dried } \\
\text { extract } /\left(\mathrm{g} \mathrm{g}^{-1}\right)\end{array}$ & $\begin{array}{c}\text { Bergenin in dried } \\
\text { bark / }(\%)\end{array}$ \\
\hline 254 & 60.0 & 0.267 & 0.240 & 3.18 \\
215 & 64.0 & 0.569 & 0.256 & 3.39 \\
272 & 60.2 & 0.485 & 0.241 & 3.19 \\
\hline
\end{tabular}

equation found was $y=39.827 x-42.012$, with a correlation coefficient of 1.0000 . At $215 \mathrm{~nm}$, the regression equation found was $\mathrm{y}=222.960 \mathrm{x}-217.065$, with a correlation coefficient of 0.9999 . The inter-day analysis calibration curve of bergenin had CV\% values inferior to $6 \%$.

Because of the higher selectivity of bergenin at $272 \mathrm{~nm}$, the concentration of bergenin was calculated solely on the basis of the chromatograms extracted at $272 \mathrm{~nm}$. The aqueous extract of bark of E. uchi prepared at a concentration of $250 \mu \mathrm{g} \mathrm{mL}^{-1}$ was analyzed in duplicate and bergenin contents were determined as being $60.2 \mu \mathrm{g} \mathrm{mL} \mathrm{m}^{-1}$ (Table 2). Considering the extractive yield of $13.3 \%$, the concentration of bergenin in the dried barks was $3.19 \%$.

These results confirm that bergenin is the main constituent of $E$. uchi tea bark and is very likely to be responsible for the anti-inflammatory activity of the tea bark used in traditional medicine.

\section{Acknowledgments}

This work is dedicated to Prof. Otto Richard Gottlieb who have inspired generations of natural product chemists in Brazil. We would like to thank CNPq (Proc. N. 553235/2005-2) and FAPEAM for their financial support and stipends, the CBA for the NMR spectral analysis.

\section{References}

1. Gottlieb, O. R.; Mors, W. B.; Interciencia 1987, 3, 252.

2. Gottlieb, O. R.; Kaplan, M. A. C.; Ciência Hoje 1990, 11, 17.

3. Schultes, R. E.; Lloydia 1962, 25, 145.

4. Marx, F.; Andrade, E. H. A.; Zoghbi, M. G.; Maia, J. G. S.; Eur. Food Res. Technol. 2002, 214, 331.

5. Magalhães, L. A.; Lima, M. P.; Marinho, H. A.; Ferreira, A. G.; Acta Amaz. 2007, 37, 447.

6. Corrêa, M. P.; Dicionário das Plantas Úteis do Brasil e das Exóticas Cultivadas, Imprensa Nacional: Rio de Janeiro, Brasil, 1984, vol. 6, p. 326.

7. Revilla, J.; Plantas da Amazônia. Oportunidades Econômicas Sustentáveis, INPA/SEBRAE: Manaus, Brasil, 2001.

8. Caldas, C. S.; De Simone, C. A.; Pereira, M. A.; Malta, V. R. S.; Carvalho, R. L. P.; Da Silva, T. B. C.; Sant'ana, A. E. G.;
Conserva, L. M.; Acta Crystallogr., Sect. E: Struct. Rep. 2002, $58,609$.

9. Ogan, A. U.; Phytochemistry 1971, 10, 2832.

10. Swarnalakshmi, T.; Seth Raman, M. G.; Sulochana, N.; Arivudainambi, R.; Curr. Sci. 1984, 53, 917.

11. Nazir, N.; Koul, S.; Qurishi, M. A.; Taneja, S. C.; Ahmad, S. F.; Bani, S.; Qazi, G. N.; J. Ethnopharmacol. 2007, 112, 401.

12. Sumino, M.; Sekine, T.; Ruangrungsi, N.; Igarashi, K.; Ikegami, F.; Chem. Pharm. Bull. 2002, 50, 1484.

13. Lim, H. K.; Kim H. S.; Choi, H. S.; Oh, S.; Choi, J.; J. Ethnopharmacol. 2000, 72, 469.

14. Takahachi, H.; Kosaka, M.; Watanabe, Y.; Nakade, K.; Fukuyama, Y.; Bioorg. Med. Chem. 2003, 11, 1781.

15. Piacente, S.; J. Nat. Prod. 1996, 59, 565.

16. Prithiviraj, B.; Singh, U. P.; Manickam, M.; Srivastava, J. S.; Ray, A. B.; Plant Pathol. 1997, 46, 224.

17. Da Silva, S. L.; Oliveira, V. G.; Yano. T.; Nunomura, R. C. S.; Acta Amaz. 2009, 38, 187.

18. Rastogi, P.; Beckett, C. S.; McHowat, J.; Prostaglandins, Leukotrienes Essent. Fatty Acids 2007, 76, 205.

19. Michaluart, P.; Masferrer, J. L.; Carothers, A. M.; Subbaramaiah, K; Zweifel, B. S.; Koboldt, C.; Mestre, J. R.; Grunberger, D.; Sacks, P. G.; Tanabe, T.; Dannenberg, A. J.; Cancer Res. 1999, 59, 2347.

20. Molina-Holgado, E.; Ortiz, S.; Molina-Holgado, F.; Guaza, C.; Br. J. Pharmacol. 2000, 131, 152.

21. Seo, E.; Chai, H.; Constant, H. L.; Santisuk, T.; Reutrakul, V.; Beecher, C. W. W.; Farnsworth, N. R.; Cordell, G. A.; Pezzuto, J. M.; Kinghorn, A. D.; J. Org. Chem. 1999, 64, 6976.

22. Jahodar, I.; Kolb, I.; Lioka, A.; Fitoterapia 1992, 63, 260.

23. Murias, M.; Handler, N.; Erker, T.; Pleban, K.; Ecker, G.; Saiko, P.; Szekeres, T.; Jäger, W.; Bioorg. Med. Chem. 2004, 12, 5571 .

24. Souza, A. D. L.; Rodrigues-Filho, E.; Souza, A. Q. L.; Pereira, J. O.; Calgarotto, A. K.; Maso, V.; Marangoni, S.; Da Silva, S. L.; Toxicon 2008, 51, 240.

25. Siqueira Jr., J. M; Peters, R. R.; Gazola, A. C.; Krepsky, P. B.; Farias, M. R.; Rae, G. A.; Brum-Fernandes, A. J.; Ribeiro-doValle, R. M.; Life Sci. 2007, 80, 13.

Received: January 31, 2009 Web Release Date: June 12, 2009 